No 4078

Studia nad Autorytaryzmem i Totalitaryzmem 43, nr 4 Wrocław 2021

https://doi.org/10.19195/2300-7249.43.4.22

AGNIESZKA CHRISIDU-BUDNIK

ORCID: 0000-0001-7775-241X

Uniwersytet Wrocławski

agnieszka.chrisidu-budnik@uwr.edu.pl

\title{
Z problematyki emigracji z Grecji do Polski Ludowej
}

Slowa kluczowe: uchodźcy, emigracja, wojna domowa.

\section{ISSUES OF EMIGRATION FROM GREECE TO THE POLISH PEOPLE'S REPUBLIC}

\begin{abstract}
The 1944-1949 Greek civil war between the supporters of the monarchy with the right-wing government and the left-wing forces with the Democratic Army of Greece resulted in the death of approximately 100,000 people and forced partisans and their families to migrate to countries of "people's democracy." It is estimated that the Polish People's Republic accepted approximately 14,000 people (children and adults). The article describes the genesis of the conflict that led to the outbreak of the civil war as well as the increasing polarization of the Greek population. It presents the (political and social) complexity of the processes of emigrating from Greece to the people's democracies and selected aspects of the organization of the Greek community's life in the Polish People's Republic.
\end{abstract}

Keywords: refugees, emigration, civil war.

\section{Geneza}

Geneza procesów uchodźstwa Greków do krajów ówczesnej demokracji ludowej ma korzenie w wojnie domowej, która stanowiła apogeum zapoczątkowanego w 1915 roku podziału narodu greckiego na zwolenników monarchii i zwolenników republiki ${ }^{1}$. Polaryzacja społeczeństwa greckiego pogłębiła się wraz z powstaniem

${ }^{1}$ Rozłam na monarchistów skupionych wokół osoby króla Konstantyna I i republikanów będących zwolennikami polityki premiera Elefteriosa Wenizelosa, określany mianem narodowej

Studia nad Autorytaryzmem i Totalitaryzmem 43, nr 4, 2021

(C) for this edition by CNS 


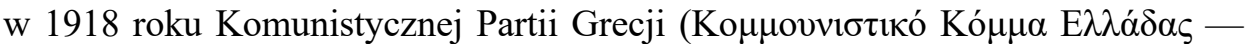
KKE). Czasowe stłumienie napięć na greckiej scenie politycznej nastąpiło w trakcie wojny włosko-greckiej (1940-1941). Odrzucenie przez ówczesnego premiera Joanisa Metaksasa włoskiego ultimatum dotyczącego zgody na swobodny przemarsz wojsk włoskich przez terytorium Grecji de facto oznaczało rozpoczęcie wojny. Sprzeciw wobec wystosowanego przez Włochy ultimatum (wyrażony

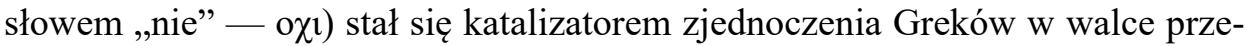
ciw okupacji włoskiej i początkiem formowania się greckiego ruchu oporu². Istotne znaczenie dla konsolidacji Greków miała odezwa działacza KKE Nikosa Zachariadisa, który wezwał do zjednoczenia wszystkich stron sporu politycznego wokół rządu Metaksasa w walce o wyzwolenie narodowe ${ }^{3}$. Późniejsza interwencja wojsk III Rzeszy po stronie Włoch doprowadziła do podpisania 23 kwietnia 1941 roku w Larisie układu o zawieszeniu broni i faktycznie oznaczała kapitulację armii greckiej oraz początek wspólnej niemiecko-włoskiej okupacji, do której dołączyła Bułgaria ${ }^{4}$.

Podczas okupacji szczególnie skuteczne w organizacji ruchu oporu okazały się siły lewicowe. Nauczywszy się zasad konspiracji i działalności w podziemiu (dyktatura premiera Metaksasa i wojna włosko-grecka), w czasie okupacji wykazały się dużą dynamiką działań ${ }^{5}$. Spośród ugrupowań lewicowych największą rolę polityczną odegrał utworzony we wrześniu 1941 roku Front Wyzwolenia Narodowego

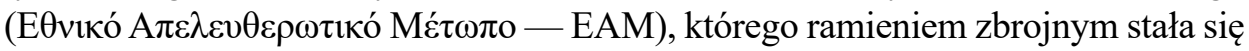

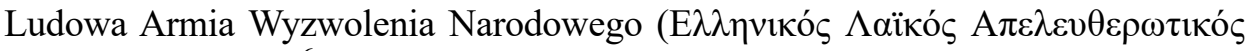
$\Sigma \tau \rho \alpha \tau o ́ \varsigma-E L A S)^{6}$. Wśród prawicowych ugrupowań partyzanckich największe

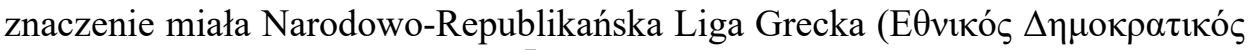

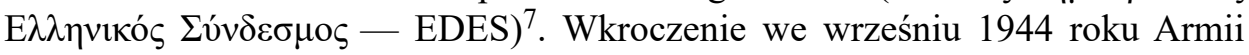
Czerwonej na Bałkany uruchomiło procesy ewakuacji wojsk okupacyjnych z terytorium Grecji. 26 września 1944 roku we włoskiej miejscowości Caserta doszło do zawarcia porozumienia pomiędzy przebywającym na uchodźstwie rządem,

schizmy ( $\varepsilon \theta v ı \kappa o \varsigma \delta \imath \chi \alpha \sigma \mu \varsigma)$, stanowił pokłosie odmiennych zapatrywań króla i premiera na aktywność Grecji podczas I wojny światowej. Król Konstantyn spokrewniony poprzez swoją żonę Zofię z cesarzem Wilhelmem II optował za zaangażowaniem się Grecji w konflikt zbrojny po stronie Niemiec (trójprzymierze). Rząd Wenizelosa opowiadał się za neutralnością kraju, a w razie konieczności - za zaangażowaniem po stronie trójporozumienia; zob. G. Mavrogordátos, 1915 O ethnikos dichasmos, Athína 2015, passim.

2 S. Melás, Ioánnīs Metaxás. O stratiótīs, o politikós, o kyvernitīs, Athína 2016, passim.

3 Zob. J.C. Loulis, The Greek Communist Party (KKE) and the Greek-Italian War, 19401941: an Analysis of Zahariadis' Three Letters, „Byzantine and Modern Greek Studies” 5, 1975.

4 Zob. J. Carr, The Defence and Fall of Greece 1940-1941, South Yorkshire 2013; M. Mazower, Inside Hitler's Greece: The Experience of Occupation, 1941-44, London 1993, passim.

${ }^{5}$ Zob. J. Bonarek et al., Historia Grecji, Kraków 2005, s. 585.

6 Zob. I.G. Chandrinós, Póleis se pólemo 1939-1945, Evropaïká astikákéntra ypó germanikí katochí, Athína 2018, passim.

7 S.N. Kalývas, Emfýlios Pólemos (1943-1949): To télos tonmýthon kai īstrofí pros tomazikó epípedo, „Epistímī kai Koinonía” 2003, nr 11. 
na którego czele stał premier Georgios Papandreou, a głównymi ugrupowaniami partyzanckimi ELAS i EDES oraz Brytyjczykami. Zgodnie z postanowieniami porozumienia siły greckiego ruchu oporu zostały podporządkowane dowództwu korpusu brytyjskiego, który 14 października 1944 roku zajął Ateny. Pomimo zawartego w Casercie porozumienia w kraju narastał konflikt polityczny pomiędzy Brytyjczykami a EAM. Zarzewiem konfliktu był stosunek do kolaborantów Brytyjczycy chcieli potraktować ich jako jeńców wojennych, podczas gdy EAM/ ELAS powoływały trybunały ludowe i sądy wojenne, które skazywały kolaborantów na śmierć lub więzienie. Jednocześnie niepodważalne znaczenie EAM/ ELAS w walce $\mathrm{z}$ okupantem oraz ich wkład w powodzenie ofensywy sowieckiej na Bałkanach komplikowały stabilizację sytuacji politycznej w Grecji, naruszając interesy Brytyjczyków w Grecji ${ }^{8}$.

W listopadzie stojący na czele Rządu Jedności Narodowej premier Jorgos Papandreou rozwiązał oddziały ELAS i nakazał im złożenie broni. W odpowiedzi na to przedstawiciele EAM wycofali się z mającego wsparcie brytyjskie rządu Papandreou, a w Atenach wybuchły zaciekłe walki, zwane wydarzeniami grudniowymi, podczas których lewicowe przedmieścia zostały ostrzelane przez samoloty RAF ${ }^{9}$. W czasie starć zbrojnych zginęło około 7-11 tysięcy osób, a ponad 20 tysięcy zostało rannych ${ }^{10}$. Wydarzenia grudniowe stały się początkiem wojny domowej w Grecji. Od lutego 1945 roku rozpoczęła się sukcesywna ekskluzja z greckiej sceny politycznej silnego i stabilnego organizmu, jaki stanowiły połączone siły EAM/ELAS. Zawarty 12 lutego 1945 roku układ w Warkizie — formalnie kończący wydarzenia grudniowe - przewidywał rozbrojenie podległych EAM oddziałów ELAS, powszechną amnestię i rozliczenie kolaborantów z okresu okupacji niemieckiej. Jednak wspierany przez Brytyjczyków prawicowy rząd zaczął szukać oparcia wśród antykomunistów i kolaborantów (tę politykę kontynuowały późniejsze gabinety ${ }^{11}$. Do Grecji sprowadzono 4 Dywizję Piechoty, której desant poprzez zwiększenie liczebności wojsk brytyjskich miał pomóc w stabilizacji kraju.

${ }^{8}$ EAM/ELAS, opowiadając się za wolną Grecją, naruszały postanowienia tak zwanego porozumienia procentowego (percentages agreement) — nieformalnego, tajnego układu zawartego w październiku 1944 roku pomiędzy Winstonem Churchillem a Józefem Stalinem, w którym to układzie ustalono, ile władzy w Bułgarii, Rumunii, Jugosławii, Grecji i na Węgrzech będą mieli zachodni koalicjanci, a ile - ZSRR. W ramach porozumienia Wielka Brytania miała zachować dziewięćdziesięcioprocentowe wpływy w Grecji. Zob. A. Resis, The Churchill-Stalin Secret „Percentages" Agreement on the Balkans, Moscow, October 1944, „The American Historical Review” 83, 1978, nr 2.

${ }^{9}$ Por. M. Mazower, Saloniki. Miasto duchów. Chrześcijanie, muzulmanie i żydzi w latach 1430-1950, przeł. A. Nowakowska, Wołowiec 2017, s. 522.

10 S. Górski, Grecka wojna domowa w świetle polskiej prasy krajowej w latach 1944-1949, Wrocław 2011, s. 59.

11 Ibidem, s. 60. 


\section{Wojna domowa (1946-1949)}

Podczas gdy Europa i Stany Zjednoczone po zakończeniu II wojny światowej zaczęły tworzyć zaplecze legislacyjne i infrastrukturalne wspomagające modernizację gospodarek państw uczestniczących w koalicji antyfaszystowskiej, Grecja pogrążyła się w wojnie domowej ${ }^{12}$. Mimo porozumienia z Warkizy w państwie

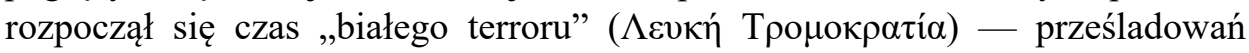
i represji wobec członków KKE, EAM i ELAS. Równocześnie amnestią objęto grecką kolaborującą grupę wojskową - Bataliony Bezpieczeństwa (Tó $\gamma \mu \alpha \tau \alpha$ A $\sigma(\alpha \lambda \varepsilon i ́ \alpha \varsigma)$. Po stronie lewicowej polaryzację pogłębiał Nikos Zachariadis, który przeforsował decyzję o zbojkotowaniu powszechnych wyborów przez komunistów, co doprowadziło do ostatecznego rozłamu politycznego. Wybory przeprowadzone w marcu 1946 roku wygrała prawica, we wrześniu tego samego roku po pięciu latach pobytu w Anglii powrócił do Aten król Jerzy II, co symbolicznie wzmocniło rządy rojalistów pod auspicjami brytyjskimi. W tym samym miesią-

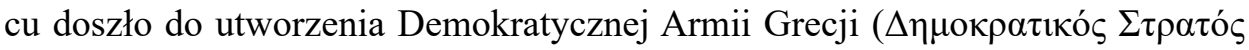
E $\lambda \lambda \alpha ́ \delta \alpha \varsigma$ — DSE), a w październiku utworzono Naczelne Dowództwo Partyzantów, na którego czele stanął członek KKE i dawny oficer polityczny ELAS Markos Wafiadis. Rojaliści mieli znaczną przewagę nad DSE, dysponując siłami przekraczającymi ponad 100 tysięcy ludzi. DSE pod koniec 1946 roku liczyła około 20 tysięcy członków, ale były to oddziały lepiej wyszkolone, dobrze zorganizowane, zdyscyplinowane i zaprawione $\mathrm{w}$ walce partyzanckiej ${ }^{13}$.

Stroną ofensywną od początku wojny byli partyzanci, którzy siłowo zajmowali posterunki policji, garnizony wojskowe, zdobywali kolejne miejscowości. Na terenach, które kontrolowała DSE, pojawiły się atrybuty „wolnej Grecji” — tworzono administrację, zbierano podatki, organizowano regularny pobór do wojska, prowadzono działalność propagandową. W 1947 roku pod kontrolą DSE znalazło się blisko $60 \%$ terytorium kontynentalnej Grecji ${ }^{14}$. Mimo to partyzanci zaczęli przegrywać starcia o kolejne miasta mające strategiczne znaczenie (Konitsa, Florina), a inicjatywa przeszła w ręce sił rządowych. Można wskazać na przynajmniej dwie główne przyczyny, które stopniowo doprowadziły do klęski partyzantów.

Pierwsza to konflikt interpersonalny, który powstał pomiędzy Wafiadisem a Zachariadisem. U podstaw sporu legły ambicje polityczne obydwu polityków, odmienne podejście do taktyki działań zbrojnych oraz opowiedzenie się Zachariadisa po stronie Moskwy w konflikcie między Związkiem Radzieckim a Socjalistyczną Federacyjną Republiką Jugosławii. Pokłosiem sporu było usunięcie w 1948 roku Wafiadisa, mającego duże doświadczenie wojskowe, z kierownictwa DSE. Wówczas doszło do porzucenia skutecznej partyzanckiej taktyki „uderzaj

12 Zob. A. Nachmani, Civil War and Foreign Intervention in Greece: 1946-49, „Journal of Contemporary History” 25, 1990, $\mathrm{nr} 4$.

13 Por. J. Bonarek et al., op. cit., s. 598.

14 Por. A. Morawski, Góry Pindos 1943-1949, Warszawa 2013, s. 94-95. 
i znikaj" na rzecz otwartej walki, co doprowadziło do militarnych porażek i ostatecznej przegranej.

Drugą przyczyną było wsparcie finansowe, które w wyniszczonym okupacją państwie greckim dla każdej ze stron konfliktu miało zasadnicze znaczenie w drodze do zwycięstwa. Bez stałej aprowizacji ze strony państw demokracji ludowej oraz Wielkiej Brytanii, a od 1947 roku Stanów Zjednoczonych, grecka wojna domowa zakończyłaby się znacznie wcześniej - o ile w ogóle by się rozpoczęła ${ }^{15}$. Związek Radziecki, po cichu wspierający DSE, nie zajął jednoznacznego stanowiska - Stalin nigdy oficjalnie nie opowiedział się po stronie partyzantów przez co utrzymywał iluzję respektowania brytyjsko-sowieckiej umowy procentowej ${ }^{16}$. Mimo to DSE otrzymywała nieoficjalną pomoc logistyczną oraz wsparcie medyczne i wojskowe z Jugosławii, Albanii, Bułgarii i Polski ${ }^{17}$. Strona rządowa skupiona wokół króla Jerzego II otrzymywała początkowo wsparcie finansowe z Wielkiej Brytanii, którą zastąpiły neutralne do 1947 roku Stany Zjednoczone. 12 marca 1947 roku prezydent Harry Truman przedstawił przed połączonymi izbami Kongresu program, zwany doktryną Trumana, w którym podkreślał konieczność pomocy dla Grecji i Turcji ${ }^{18}$. Udzielona w ramach doktryny Trumana pomoc była nadzorowana przez Amerykańską Misję Pomocy dla Grecji (American Mission for Aid to Greece - AMAG). Równolegle do AMAG na terenie Grecji rozpoczęła działalność grupa doradców wojskowych w ramach struktury określanej mianem JUSMAPG (Joint US Military Advisory and Planning Group Greece), na której czele stanął, odpowiedzialny za wdrożenie doktryny Trumana, generał James Van Fleet ${ }^{19}$.

1 maja 1949 roku rozpoczęto operację „Rocket”, w której trakcie jednostki DSE zostały wyparte z obszaru Tesalii i Rumelii; tym samym centralna część kraju stała się wolna od sił lewicowych. Trudne położenie partyzantów komplikowała sytuacja na scenie politycznej powstała wskutek konfliktu pomiędzy Stalinem a Tito. W toczącym się sporze Zachariadis opowiedział się po stronie Moskwy i optował za kontynuacją walk zbrojnych, podczas gdy Wafiadis zaczął skłaniać się ku zawieszeniu broni i podjęciu rozmów z rządem wspierającym króla Jerzego II. Został za to usunięty z kierownictwa DSE, a największy sprzymierzeniec DSE,

15 Por. N. Marantzidis, Wojna domowa w Grecji (1944-1949) i otwarcie archiwów w postkomunistycznej Europie, [w:] PRL a wojna domowa w Grecji, red. M. Semczyszyn, Szczecin 2016, s. 42.

16 Por. M. Semczyszyn, Wojna domowa w Grecji (1944-1949) - zarys problematyki, [w:] PRL a wojna domowa..., s. 21.

$17 \mathrm{~W}$ ramach tajnych porozumień państw demokracji ludowej polska flota handlowa (jednostki: „Stalowa Wola”, „Kościuszko”, „Bałtyk”, „Wisła” i „Karpaty”) odbywały rejsy do albańskiego portu Durrës i dostarczały partyzantom broń i wyposażenie wojskowe. Zob. J. Drzemczewski, Na śródziemnomorskim szlaku 1924-2008, Gdynia 2009, s. 51-54.

18 Zob. K. Michałek, Doktryna Trumana: błąd w politycznej kalkulacji czy próba nowego podejścia do bezpieczeństwa narodowego Stanów Zjednoczonych?, „Dzieje Najnowsze” 1997, nr 2.

19 Zob. S. Zachariou, Implementing the Marshall Plan in Greece: Balancing Reconstruction and Geopolitical Security, ,Journal of Modern Greek Studies” 27, 2009, nr 2. 
Josip Broz-Tito, jedyny lider bloku państw wschodnich rzeczywiście zainteresowany wygraną partyzantów i powstaniem komunistycznej Grecji, 10 lipca 1949 roku zamknął granice, kończąc w ten sposób zaangażowanie Jugosławii w wojnę domową. 16 października 1949 roku po wyniszczających porażkach komuniści ogłosili zakończenie wojny.

Trwająca w latach 1946-1949 wojna domowa w Grecji pomiędzy siłami komunistycznymi skupionymi wokół KKE a siłami monarchistycznymi zakończyła się śmiercią około 158 tysięcy ludzi oraz zmusiła do ucieczki z kraju członków KKE, bojowników DSE i członków ich rodzin. Fala terroru, która rozpoczęła się po przegraniu przez partyzantów wojny domowej, wymusiła emigrację ludności greckiej do Jugosławii i Albanii, a stamtąd między innymi do Polski. Liczb uchodźców sięgnęła około 100 tysięcy $^{20}$. Na represje podejmowane wobec członków DSE składały się regulacje prawne uniemożliwiające uchodźcom powrót do ojczyzny i pozbawiające ich greckiego obywatelstwa.

\section{Exodus z Grecji}

Będący konsekwencją wojny domowej proces emigracji ludności greckiej składał się z dwóch etapów. Pierwszy etap rozpoczął się jeszcze w trakcie działań wojennych w 1948 roku i dotyczył tylko dzieci w wieku od drugiego do czternastego roku życia. Nieocenionego wsparcia logistycznego, materialnego i zdrowotnego udzieliła Jugosławia. Około 28 tysięcy dzieci - sierot lub rozłączonych z rodzinami - małymi grupami pod nadzorem przewodników i opiekunek, tak zwanych majek, przeszło przez góry północnej Grecji na teren dzisiejszej Macedonii Północnej. Pokłosiem konfliktu Stalin-Tito była kolejna emigracja dzieci, to znaczy rozmieszczenie ich w krajach, które w trakcie wojny domowej wspierały KKE w Czechosłowacji, Rumunii, NRD, na Węgrzech i w Polsce ${ }^{21}$. Wywóz dzieci do państw socjalistycznych określany jest $\mathrm{w}$ greckiej historiografii jako paidomázoma $(\pi \alpha 1 \delta \rho \mu \alpha ́ \zeta \omega \mu \alpha)$ - dzieci oderwano od rodziców, wywieziono do obcych państw, skoszarowano w sierocińcach, wychowano w ideologicznej indoktrynacji i w rygorze wojskowym na przyszłych bojowników o wolną (komunistyczną) Grecję ${ }^{22}$.

${ }^{20}$ Uchodźcy z Grecji w Polsce nie stanowili grupy jednolitej pod względem etnicznym i narodowościowym. Pierwszą grupę stanowili Macedończycy — autochtoniczna ludność słowiańska skupiona wokół miast Florina i Kastoria na północy Grecji; drugą grupę, pochodzenia romańskiego, stanowili Wołosi; najliczniejszą zaś stanowiła etniczna ludność grecka. Zob. A. Kurpiel, Uchodźcy z greckiej wojny domowej na Dolnym Ślasku —zarys problematyki, [w:] Ziemie Zachodnie — historia i perspektywy, red. W. Kucharski, G. Strauchold, Wrocław 2012.

21 Zob. L.M. Danforth, R. Van Boeschoten, Children of the Greek Civil War. Refugees and the Politics of Memory, Chicago-London 2012, s. 594-595.

22 Por. A. Nowosad, Greckie dzieci wojny - paidomázoma i powrót do domu, [w:] Przestrzenne kody tekstów i narracyjne kody przestrzeni, red. B. Zieliński, Poznań 2013, s. 301. 
W Polsce dzieci zakwaterowano w specjalnie do tego przeznaczonych placówkach oświatowo-wychowawczych, największe z nich mieściły się w Zgorzelcu i Policach. Bezpośredni nadzór nad działalnością tych placówek sprawowali członkowie KKE, którzy po przybyciu z terenu Albanii do Polski żywili złudne nadzieje na rychły powrót do kraju i wznowienie walk. Ośrodki oświatowo-wychowawcze miały charakter zamknięty i poufny (personel został zobowiązany do nieujawniania żadnych informacji na ich temat). Dlatego też akty prawne lub wytyczne dotyczące nauczania były opatrywane klauzulami „tajne” lub „poufne”23. Tajność ośrodków oświatowo-wychowawczych stanowiła odzwierciedlenie ówczesnej polityki: ,regulacje cudzoziemskie okresu powojennego były kształtowane pod wpływem komunistycznego izolacjonizmu, zakładającego nadzór państwa nad każdym aspektem kontaktów z zagranicą"24.

Drugi etap objął przede wszystkim dorosłą ludność - partyzantów i ich rodziny z niewielkim udziałem dzieci (zazwyczaj do drugiego roku życia), którzy po przegranej wojnie w 1949 roku przedostali się z Epiru do Albanii (granice z Jugosławią zostały już zamknięte), skąd drogą morską zostali wysłani do Polski Ludowej, a stamtąd do innych państw bloku wschodniego.

Grecy i Macedończycy przybyli do Polski jako uchodźcy polityczni. Polska Ludowa pozostawała, podobnie jak i inne kraje bloku wschodniego, poza międzynarodowym systemem opieki nad uchodźcami, opartym na konwencji genewskiej z 1951 roku i związanym z urzędem Wysokiego Komisarza Organizacji Narodów Zjednoczonych ds. Uchodźców. Mimo to władze PRL udzieliły uchodźcom z Grecji azylu politycznego na podstawie art. 75 Konstytucji z 1952 roku $^{25}$, który stanowił: „Polska Rzeczpospolita Ludowa udziela azylu obywatelom państw obcych, prześladowanym za obronę mas pracujących, walkę o postęp społeczny, działalność w obronie pokoju, walkę narodowowyzwoleńczą lub działalność naukową". Ponieważ powołany po wojnie domowej prawicowy rząd grecki w drodze dekretów pozbawił uchodźców obywatelstwa (dekret LZ/1947) oraz prawa własności (dekret M/1948), w Polsce Ludowej uzyskali status bezpaństwowca i azyl polityczny.

Zaangażowanie w walkę o budowę ,wolnej” Grecji i silna identyfikacja z aksjologią komunistyczną przyczynily się do traktowania uchodźców niemal jako autochtonicznej mniejszości narodowej — formalnie przysługiwały im niemal wszystkie prawa nadane obywatelom Polski, z wyłączeniem nabywania na własność nieruchomości i posiadania polskich paszportów ${ }^{26}$. Uchodźcy, choć

${ }^{23}$ Zob. B. Techmańska, Szkolnictwo dla mniejszości narodowych na Dolnym Śląsku w okresie PRL. Wybrane zagadnienia, „Klio” 38, 2016, nr 3.

24 P. Dąbrowski, Cudzoziemiec niepożądany w polskim prawie o cudzoziemcach, Warszawa 2011, s. 62.

25 Konstytucja Polskiej Rzeczypospolitej Ludowej z 22 lipca 1952 roku (Dz.U. z 1952 r. Nr 33, poz. 232).

26 Por. A. Słabig, ,,Przybysze”. Dokumenty do dziejów uchodźców politycznych z Grecji w zbiorach oddziału Instytutu Pamięci Narodowej w Poznaniu, „Słupskie Studia Historyczne” 2006, nr 12, s. 227. 
podlegali polskiemu prawodawstwu, do początku lat pięćdziesiątych XX wieku stanowili hermetyczną zbiorowość. Cieszyła się ona, przy cichej akceptacji władz ówczesnej PRL, dużą autonomią, w której ramach rządziła się wewnętrznymi nieformalnymi regułami, sprzecznymi czasem z polskim prawem ${ }^{27}$. Sytuacja uległa normalizacji dopiero w połowie lat pięćdziesiątych, gdy władze KKE w Polsce podjęły intensywną i oficjalną współpracę z PZPR i w ten sposób ujawniły na arenie międzynarodowej pobyt uchodźców z Grecji w Polsce Ludowej.

Pomimo intensyfikacji współpracy grecko-polskiej, której ideologiczne spoiwo stanowiła walka z imperializmem o komunistyczne ideały, uchodźcy byli poddani intensywnej inwigilacji przez polskie organy bezpieczeństwa. Znajdowali się pod stałą obserwacją prowadzoną przez IV Wydział I Departamentu MBP (kontrwywiadu) o kryptonimie „R.O. Południe”28. Przedmiotem inwigilacji pozostawały zwłaszcza próby nawiązania przez greckich uchodźców kontaktów z Czerwonym Krzyżem i ambasadami krajów kapitalistycznych celem odnalezienia rodzin. Równocześnie uchodźcy wysyłali pisma do Bolesława Bieruta, Ministerstwa Bezpieczeństwa Publicznego, Komitetu Centralnego PZPR, Ministerstwa Spraw Zagranicznych z prośbą o połączenie z rodzinami, które znalazły się w krajach demokracji ludowej, Kanadzie czy Australii. Podejmowane próby łączenia rodzin, których jedna część znalazła się w krajach demokracji ludowej, a druga — w Kanadzie lub Australii, zazwyczaj były niezwykle skomplikowane i mało skuteczne ${ }^{29}$. Wyższy stopień skuteczności cechował łączenie rodzin (zazwyczaj dzieci odłączonych od rodziców) w ramach krajów bloku wschodniego. Rozłąka była spowodowana tym, że jak już wspomniano, emigracja odbywała się dwuetapowo, najpierw wyprowadzono dzieci z Grecji na teren dzisiejszej Macedonii Północnej, a dopiero potem nastąpiła ucieczka zdziesiątkowanych oddziałów partyzanckich do Albanii. Polska Ludowa przejęła opiekę nad Grekami przyjeżdżającymi do Polski w ramach procesów łączenia rodzin i zapewniła zakwaterowanie, wyposażenie i remont obiektów mieszkalnych oraz zaopatrzenie w odzież, bieliznę i obuwie ${ }^{30}$.

\section{Powrót}

Normalizacja stosunków między Polską Rzecząpospolitą Ludową a Socjalistyczną Federacyjną Republiką Jugosławii po 1956 roku otworzyła przestrzeń dla

27 Przykład stanowiły śluby i rozwody udzielane przez funkcjonariuszy KKE, które w świetle polskich regulacji prawnych prowadziły niekiedy do przestępstwa bigamii (pierwszy małżonek w Grecji, drugi w Polsce).

28 Por. A. Kurpiel, op. cit., s. 164; zob. też M. Semczyszyn, Działania cywilnych organów bezpieczeństwa PRL wobec uchodźców z Grecji, [w:] PRL a wojna domowa..., s. 198-200.

29 Zob. J. Damousi, The Greek Civil War and Child Migration to Australia: Aileen Fitzpatrick and the Australian Council of International Social Service, „Social History” 37, 2012, nr 3.

30 Por. I. Kubasiewicz, Emigranci z Grecji w Polsce Ludowej. Wybrane aspekty z życia mniejszości, [w:] Letnia Szkoła Historii Najnowszej 2012. Referaty, red. K. Dworaczek, Ł. Kamiński, Warszawa 2013, s. 115. 
rozmów na temat powrotu Macedończyków. W latach 1958-1968 Polskę opuściło około 5300 rodzin macedońskich. Bardziej złożone okazały się procesy powrotu Greków do ojczyzny. Dla prawicowych rządów uchodźcy w krajach demokracji ludowej nie istnieli, jak już wspomniano - pozbawiono ich obywatelstwa, tym samym nie było akceptacji dla ich repatriacji. Sytuacja zmieniła się dopiero po upadku junty czarnych pułkowników w 1974 roku — zalegalizowano partię KKE, grecki polityk Andreas Papandreou utworzył partię centrolewicową PASOK. Już w 1975 roku rozpoczęły się pierwsze - sporadyczne — powroty uchodźców do ojczyzny. Sytuacja zmieniła się diametralnie w 1981 roku, gdy wybory parlamentarne wygrał PASOK. W 1982 roku rząd Papandreou przegłosował ustawę o amnestii (ustawa 106841/1982). Umożliwiała ona powrót do kraju uchodźcom, którzy zostali zmuszeni do opuszczenia ojczyzny w trakcie trwania wojny domowej. W 1985 roku przyjęto ustawę o restytucji mienia (ustawa 1540/1985), na mocy której umożliwiono prawnie dochodzenie zwrotu mienia odebranego uchodźcom dekretem z 1948 roku. Od 1982 roku rozpoczą się okres masowych powrotów do Grecji. Szacuje się, że Polskę opuściło wówczas około 5500 ludzi, $\mathrm{z}$ tego prawie 250 małżeństw mieszanych etnicznie (polsko-greckich) ${ }^{31}$. Pomimo przyjętych regulacji prawnych, w zamierzeniu ułatwiających powrót emigrantów do kraju, władze greckie w niczym nie wspierały adaptacji Greków powracających z uchodźstwa, ani pod względem ekonomicznym, ani społecznym.

\section{Uwagi końcowe}

Problematyka emigracji politycznej w wyniku wojny domowej (1946-1949) w Grecji jest zagadnieniem złożonym. Źródła konfliktu tkwią w polaryzacji społeczeństwa greckiego, która ujawniła się już na początku XX wieku. Na przebieg wojny wpływ miały nie tylko zaangażowane w nią strony - prawica popierająca rząd i monarchię oraz lewica zrzeszona w oddziałach DSE — lecz także, a może przede wszystkim, sytuacja międzynarodowa w powojennej Europie. Determinacja bloku zachodniego w utrzymaniu państwa greckiego w orbicie swoich wpływów, czemu towarzyszyła pasywna postawa Związku Radzieckiego i brak przeświadczenia Stalina o realnej możliwości wygrania wojny domowej przez DSE, przesądziła o wyniku konfliktu. Sytuację sił lewicowych w schyłkowym okresie wojny skomplikował konflikt na linii Stalin-Tito. Z perspektywy partyzantów najistotniejszy był fakt zamknięcia granicy grecko-jugosłowiańskiej w wyniku rzeczonego konfliktu, co pogłębiło rozdzielenie rodzin i utrudniło w latach pięćdziesiątych XX wieku procesy ich odnajdywania i łączenia w poszczególnych krajach demokracji ludowej.

Przybycie uchodźców do Polski Ludowej, uwarunkowane klęską sił lewicowych, przebiegało dwutorowo, to znaczy dotyczyło dzieci z obszarów objętych

31 Por. K. Pudło, Grecy i Macedończycy w Polsce 1948-1993. Imigracja, przemiany i zanikanie grupy, „Sprawy Narodowościowe. Seria Nowa” 4, 1995, z. 1, s. 136.

Studia nad Autorytaryzmem i Totalitaryzmem 43, nr 4, 2021

(C) for this edition by CNS 
działaniami wojennymi, przetransportowanych z Jugosławii w 1949 roku między innymi do Polski, oraz dorosłych sukcesywnie przybywających (zazwyczaj z pomocą Polskiego Czerwonego Krzyża w ramach łączenia rodzin) do państwa polskiego. Polska Rzeczpospolita Ludowa wywarła istotny wpływ na sytuację uchodźców wojennych, udzieliła im azylu politycznego i przyznała status bezpaństwowców. Na potrzeby Greków w latach 1948-1951 utworzono ośrodki szkolno-wychowawcze, które do roku 1956 pozostawały placówkami zamkniętymi i utajnionymi. Niebagatelne znaczenie miała działalność opiekuńcza wobec przybywających do Polski, obejmująca między innymi wsparcie materialne i edukacyjne. Dzięki temu ostatniemu wielu imigrantów, którzy przybyli do Polski jako dzieci, skończyło tu studia. Równolegle władze PRL za pomocą rodzimych organów bezpieczeństwa prowadziły intensywną inwigilację przybyłych. Wskazać należy na przynajmniej dwa powody inwigilacji. Pierwszy wynikał z chęci uchodźców do nawiązania kontaktów i łączenia się z rodzinami, które w wyniku perturbacji wojennych znalazły się w bloku państw zachodnich (Kanada, Australia). Drugi był uwarunkowany faktem, że przybyli do Polski uchodźcy nie stanowili grupy jednolitej etnicznie — dużą jej część stanowili Macedończycy. Z powodu słowiańskiego rodowodu, a także utrzymywania sporadycznych kontaktów z rodzinami, które pozostały na terenie ówczesnej Jugosławii, Macedończycy byli traktowani jako mało wiarygodni i postrzegani jako potencjalni zwolennicy Tity ${ }^{32}$.

\section{Bibliografia}

Bonarek J. et al., Historia Grecji, Kraków 2005.

Carr J., The Defence and Fall of Greece 1940-1941, South Yorkshire 2013.

Chandrinós I.G., Póleis se pólemo 1939-1945, Evropaïká astikákéntra ypó germanikí katochí, Athína 2018.

Damousi J., The Greek Civil War and Child Migration to Australia: Aileen Fitzpatrick and the Australian Council of International Social Service, „Social History” 37, 2012, nr 3.

Danforth L.M., Van Boeschoten R., Children of the Greek Civil War. Refugees and the Politics of Memory, Chicago-London 2012.

Dąbrowski P., Cudzoziemiec niepożądany w polskim prawie o cudzoziemcach, Warszawa 2011.

Drzemczewski J., Na śródziemnomorskim szlaku 1924-2008, Gdynia 2009.

Górski S., Grecka wojna domowa w świetle polskiej prasy krajowej 1944-1949, Wrocław 2011.

Kalývas S.N., Emfýlios Pólemos(1943-1949): To télos tonmýthon kai īstrofí pros tomazikó epípedo, „Epistímī kai Koinonía” 2003, nr 11.

Konstytucja Polskiej Rzeczypospolitej Ludowej z 22 lipca 1952 roku (Dz.U. z 1952 r. Nr 33, poz. 232). Kubasiewicz I., Emigranci z Grecji w Polsce Ludowej. Wybrane aspekty z życia mniejszości, [w:] Letnia Szkoła Historii Najnowszej 2012. Referaty, red. K. Dworaczek, Ł. Kamiński, Warszawa 2013.

32 Ramy niniejszego artykułu uniemożliwiły ukazanie złożonych zagadnień dotyczących relacji macedońsko-greckich w trakcie wojny domowej, pobytu Macedończyków na emigracji w Polsce Ludowej i stosunku władz greckich do Macedończyków w latach osiemdziesiątych XX wieku po zdobyciu władzy przez PASOK. 
Kurpiel A., Uchodźcy z greckiej wojny domowej na Dolnym Ślasku - zarys problematyki, [w:] Ziemie Zachodnie - historia i perspektywy, red. W. Kucharski, G. Strauchold, Wrocław 2012.

Loulis J.C., The Greek Communist Party (KKE) and the Greek-Italian War, 1940-1941: an Analysis of Zahariadis'Three Letters, „Byzantine and Modern Greek Studies” 5, 1975.

Marantzidis N., Wojna domowa w Grecji (1944-1949) i otwarcie archiwów w postkomunistycznej Europie, [w:] PRL a wojna domowa w Grecji, red. M. Semczyszyn, Szczecin 2016.

Mavrogordátos G., 1915 O ethnikos dichasmos, Athína 2015.

Mazower M., Inside Hitler's Greece: The Experience of Occupation, 1941-44, London 1993.

Mazower M., Saloniki. Miasto duchów. Chrześcijanie, muzulmanie i żydzi w latach 1430-1950, przeł. A. Nowakowska, Wołowiec 2017.

Melás S., Ioánnīs Metaxás. O stratiótīs, o politikós, o kyvernitīs, Athína 2016.

Michałek K., Doktryna Trumana: błąd w politycznej kalkulacji czy próba nowego podejścia do bezpieczeństwa narodowego Stanów Zjednoczonych?, „Dzieje Najnowsze” 1997, nr 2.

Morawski A., Góry Pindos 1943-1949, Warszawa 2013.

Nachmani A., Civil War and Foreign Intervention in Greece: 1946-49, „Journal of Contemporary History" 25, 1990, $\mathrm{nr} 4$.

Nowosad A., Greckie dzieci wojny — paidomázoma i powrót do domu, [w:] Przestrzenne kody tekstów i narracyjne kody przestrzeni, red. B. Zieliński, Poznań 2013.

Pudło K., Grecy i Macedończycy w Polsce 1948-1993. Imigracja, przemiany i zanikanie grupy, „Sprawy Narodowościowe. Seria Nowa” 4, 1995, z. 1.

Resis A., The Churchill-Stalin Secret „Percentages” Agreement on the Balkans, Moscow, October 1944, „The American Historical Review” 83, 1978, nr 2.

Semczyszyn M., Działania cywilnych organów bezpieczeństwa PRL wobec uchodźców z Grecji, [w:] PRL a wojna domowa w Grecji, red. M. Semczyszyn, Szczecin 2016.

Semczyszyn M., Wojna domowa w Grecji (1944-1949) — zarys problematyki, [w:] PRL a wojna domowa w Grecji, red. M. Semczyszyn, Szczecin 2016.

Słabig A., „Przybysze”. Dokumenty do dziejów uchodźców politycznych z Grecji w zbiorach oddziatu Instytutu Pamięci Narodowej w Poznaniu, ,Stupskie Studia Historyczne” 2006, nr 12.

Techmańska B., Szkolnictwo dla mniejszości narodowych na Dolnym Śląsu w okresie PRL. Wybrane zagadnienia, ,Klio” 38, 2016, nr 3.

Zachariou S., Implementing the Marshall Plan in Greece: Balancing Reconstruction and Geopolitical Security, „Journal of Modern Greek Studies” 27, 2009, nr 2. 